\title{
Nurturing Entrepreneurial Learning through Mentoring ${ }^{1}$
}

\author{
Horia El Hallam \\ Research Institute on SMEs, University of Québec at Trois-Rivières \\ 3351, boul. des Forges \\ Trois-Rivières (Québec), Canada, G9A 5 H7. \\ Email: horia.elhallam@uqtr.ca,Tel: 1-819-376-5011 \#4053. \\ Étienne St-Jean \\ Research Institute on SMEs, University of Québec at Trois-Rivières \\ 3351, boul. des Forges Trois-Rivières (Québec), Canada, G9A 5 H7. \\ Email: etienne.st-jean@uqtr.ca,Tel:1-819-376-5011 \#4293.
}

\begin{abstract}
This study highlights the factors that maximize the entrepreneur's learning that occurs throughout a mentoring relationship. In order to achieve this, we conducted a hierarchical regression analysis involving a sample of 314 mentees participating in a businessmentoring program. The findings show that in order to maximize the learning from this relationship, the entrepreneur must perceive similarity and mutual trust with his or her mentor. The data shows that in exerting psychological and career-related functions, the mentor enables the entrepreneur's learning.
\end{abstract}

Keywords: Mentoring; Entrepreneurial support; Entrepreneurial learning; Novice entrepreneur

\footnotetext{
${ }^{1}$ El Hallam, H. and E. St-Jean (2016), " Nurturing Entrepreneurial Learning through Mentoring ", Journal of Developmental Entrepreneurship, Vol. 21 No. 2, 273-288. https://doi.org/10.1142/S1084946716500126
} 


\section{Introduction}

Business mentoring is gaining in popularity within entrepreneurial support organizations. Recent researches show that the novice entrepreneur's lack of experience and businessrelated skills are the main causes that could explain the mortality rate of young businesses (Hansford, Tennent, \& Ehrich, 2002; Van Gelder, De Vries, Frese, \& Goutbeek, 2007). Other studies demonstrate that psychological problems, such as: personal problems (illness, divorce) (Alred \& Garvey, 2000), entrepreneurial doubt (Valéau, 2006), isolation, and trusted people remoteness (Boyd \& Gumpert, 1983) could also put an end to the entrepreneur's entrepreneurial venture.

This is why entrepreneurial support organizations have proposed mentoring as an alternative in supporting entrepreneurs and their businesses versus traditional training. Mentoring relationships focus on the individual's professional and personal development, and each mentoring relationship is built according to the mentee's specific needs (Clutterbuck, 1999). This is what makes the mentoring relationship unique. Many studies illustrate the positive impacts generated by the mentoring and how it has helped entrepreneurs in developing cognitive (Cull, 2006; Gravells, 2006) and affective learning (Leitch et al., 2004; Nandram, 2003). Put together, they both have positive impacts on the business (Chrisman and McMullan, 2004; Deakins et al., 1998). Mentoring is then considered as a way of learning (Cope and Watts, 2000; Sullivan, 2000) and the entrepreneur's learning is considered as a variable influencing the business's success within its first years of life (Gartner et al., 1999). 
However, little is known on how the mentor contributes to the learning process. Therefore, the purpose of this study is to identify the factors that could maximize the entrepreneur's learning within a mentoring relationship. Highlighting these factors would allow support programs offering entrepreneur mentoring a better understanding on how mentors could be more effective in the learning development of the novice. Furthermore, the idea of entrepreneur mentoring is still new; therefore, limited literature is available. Thus, this study will allow us to illustrate a few theoretical underpinnings for future research.

\section{Literature Review}

Mentoring generally involves an interpersonal relationship of support, communication, and learning, where a more experienced person shares knowledge and expertise in order to help a less experienced person acquire the competence needed to achieve his or her goal (Cuerrier, 2004). The formalization of the supporting practice has developed in various environments: organizational, educational (e.g. Tedder \& Lawy, 2009), youth and community (e.g. Lunt et al., 1992), and recently, entrepreneurial. Depending on the context and the target audience, several definitions exist regarding the term "mentoring". When used in an entrepreneurial framework, mentoring is a relationship of support and guidance between an experienced business person (the mentor) and a novice entrepreneur (the mentee) (St-Jean, 2009).

Researchers have indicated the positive impacts generated by the mentoring relationship for the entrepreneur. Those impacts are usually acquired through cognitive and 
affective learning. The mentee will develop those learning outcomes under the mentor's guidance. This may be regarded as a good alternative to traditional training, taking in account that entrepreneurs value independence, on one hand, and they don't have similar needs, on the other hand (Moreland and Clark, 1992). In terms of cognitive learning, studies show that mentoring helps in identifying business opportunities (Chrisman and McMullan, 2004; Ozgen and Baron, 2007), in having better insight for business, and in increasing managerial, financial and marketing knowledge (Simard and Fortin, 2008). Regarding affective learning, other studies show that mentoring contributes in developing a sense of self-efficacy (Barnir, 2014; Nandram, 2003), self-confidence (Cull, 2006; Gravells, 2006; Leitch et al., 2004) and allows the mentee to persevere when difficult situations occur.

Mentoring would thus be a unique learning opportunity for entrepreneurs (Deakins et al., 1998; Sullivan, 2000). Gartner et al. (1999) suggests that entrepreneur learning is considered a variable that influences the business's success in its first years of life. Nonetheless, it is difficult to establish a direct relationship between the benefits of mentoring and the business's performance because some benefits are observed only later. Furthermore, numerous are the factors that can arise during that time, such as economic conjuncture and market influence. However, the key point is that whether the support given to the mentee is through assistance or counselling it implies that a learning process is underway and that the mentee's decisions will obviously have an impact on the business's development. According to Politis (2005), "entrepreneurial learning is often described as a continuous process that facilitates the development of necessary knowledge for being 
effective in starting up and managing new ventures." Several studies dedicated to entrepreneurial learning show that entrepreneurs are action oriented and that they cumulate knowledge from their own experiences (Cope, 2005; Gibb, 1997; Rae and Carswell, 2000) and from those of others (MacPherson, 2009; Miettinen, 2003). Cope (2005) also suggests that it is through the reflexivity process that experience is transformed into learning. But, Sullivan (2000) notes that it is not easy for an entrepreneur to perform reflexivity on his own when many urgent and important tasks demand immediate attention. This is why mentoring may be used effectively in support of novice entrepreneur learning. Because entrepreneur learning is mainly experiential, mentors encourage mentees to learn from their own personal experiences (Sullivan, 2000), to acknowledge their abilities and learning needs (Gravells, 2006). In doing so, the mentor supports the mentee actively and intellectually and can also act as a role model (Krueger, 1998).

\subsection{Mentoring support and learning: A conceptual framework}

Wanberg et al. (2003) suggest a formal mentoring conceptual framework, which is based on an overall review of existing literature. It shows the interaction between different variables, such as the protégé's learning ${ }^{2}$ and the likelihood of positive impacts. According to this model, the protégé's learning is considered a proximal outcome and is directly influenced by the level of mentoring received, such as the frequency of meetings and the functions exerted by the mentor. The level of mentoring received also depends on the

\footnotetext{
2 Organizational mentoring literature defines "protégé" as an employee who has a mentor. From that point, the term is used in reference to mentoring in an organizational context.
} 
characteristics of the relationship; for example, the chemistry existing between mentormentee as well as their interpersonal perceptions. Finally, these elements are determined by the mentors' and mentees' own characteristics, such as gender, age, and so on. Various studies regarding entrepreneur mentoring were influenced by other concepts that were developed in organizational settings (Simard and Fortin, 2008; Waters et al., 2002).

\subsection{Mentor's functions}

In an organizational framework, the mentor's functions refer to the different roles he or she plays in the mentoring relationship in order to support and counsel the protégé (Kram, 1983). Kram (1985) suggests that what differentiates mentoring from other interpersonal relationships are the mentor's functions. These functions are grouped in three categories: career-related functions, psychological functions, and role model function (Allen and Eby, 2004; Noe, 1988; Scandura, 1992). The career-related function aims in supporting the protégé in his professional development, while the psychological function primarily supports the protégé in his or her personal development. Lastly, the role model function illustrates the mentor's behaviour, attitude and skills that can influence the protégé's professional and private life. According to Lankau and Scandura (2002), the mentee's learning process is made easier by the functions the mentor deploys. The positive role between the mentor's functions and the mentee's learning has been illustrated in other studies (Barczyk et al., 2011; Eby et al., 2004; Wanberg et al., 2003).

Regarding entrepreneur mentoring, the mentor's functions are also likely to have a positive impact on the mentee's learning. The mentor's informational support and guidance 
could help the novice entrepreneur compensate a lack of professional skill and experience. As pointed out previously, the mentor can assist the novice entrepreneur in identifying business opportunities (Ozgen \& Baron, 2007), which is what constitutes an apprenticeship built on the mentor's career-related function. Along the same line, the mentor's psychological function allows the mentee to benefit from emotional support. By providing support, encouragement, and feedback the mentor gives the mentee the opportunity to confide and to question, which would allow the latter to build self-confidence and to enhance self-efficacy (St-Jean and Audet, 2012). Thereby, showing a positive relation between the mentor's psychological functions and the mentee's affective learning. In conclusion, the role model function would allow the mentee to relate to his or her mentor and to learn from the latter's successes and failures. As mentioned by Bandura (1999), an individual can learn from observing the behavior of someone he considers as a role model, and in doing so, assesses how to develop new skills and how to replicate more sophisticated behaviors. This suggests the potential relation between the mentor's function as a role model and the novice learning. These considerations have led us to consider the following hypothesis:

H1: Mentoring received through career-related functions has positive impacts on the mentee's learning.

H2: Mentoring received through psychological functions has positive impacts on the mentee's learning.

H3: Mentoring received through role model function has positive impacts on the mentee's learning. 


\subsection{Characteristics of the mentoring relationship}

The characteristics of a mentoring relationship influence the quality of the learning, either by improving or impeding it. Recent studies in organizational mentoring demonstrate that poor mentoring relationships often lower the mentee's learning (Eby et al., 2004; Eby and Allen, 2002). Other studies indicate that various elements, such as perceived similarity and trust, enhance the deployment of the mentor's function, which act directly on the mentee's learning development.

According to the similarity-attraction theory, Byrne (1971) demonstrates the linear relationship between individuals who share similarities (in terms of opinion, value, interest and personality), and the level of attraction. In other words, people are generally attracted to others who are similar to themselves. In an organizational environment, many researchers show that dissimilarity between individuals, for example, opinion, personality, and work styles, limits the development of an effective relationship (Eby et al., 2004, 2000; Hansford et al., 2002). Many studies show the positive relation between perceived similarity and the mentor's functions (Burke et al., 1994; Ensher et al., 2002; Turban et al., 2002; Wanberg et al., 2006). In other words, the more the dyad share similarities, the more the mentor will exert his or her functions, the better the mentee's learning will be. This suggests the following hypothesis:

H4: The level of perceived similarity between mentee and mentor has positive impacts on the mentee's learning. 
In social psychology, trust plays a key role within interpersonal relationships. According to Rempel et al. (1985), trust involves three components: predictability, dependability and faith. The first component illustrates the predictability of the future partner's behaviour, the second focuses on reliability, and the third component gives a sense of security, which allows the individual to believe that their partner will be responsive and caring no matter what happens in the future. Empirical research done in an organizational context suggests that trust in a mentoring relationship facilitates the sharing of knowledge between mentor and mentee (Alred and Garvey, 2000; Fleig-Palmer and Schoorman, 2011; Levin and Cross, 2004). In addition, just like perceived similarity, many studies show that in a mentoring relationship, trust stimulates the deployment of the mentor's functions (Bouquillon et al., 2005; Chun et al., 2010; Ragins, 1997). This leads to the following hypothesis:

H5: The mentee's level of trust regarding his or her mentor has positive impacts on the mentee's learning.

\subsection{The mentee's characteristics}

The mentee and mentor's personality plays a key role in the success of the mentoring relationship. Yet, in terms of learning, certain attributes of the mentee's personality, such as self-disclosure and learning goal orientation (LGO) may have an impact on the mentee's level of learning. 
According to Cozby (1973), self-disclosure can be defined as an interpersonal relationship where one reveals information about oneself. In a mentoring relationship, some authors note that self-disclosure increases the level of the mentoring received (Blickle et al., 2008). In other words, by sharing personal information, such as feelings and fears, the mentee stimulates the mentor's functions; those functions will have a direct impact on the mentee's learning. Wanberg et al. (2007) also note the positive relationship between self-disclosure and the positive outcomes related to the mentee's career. From an entrepreneur's point of view, it would seem logical to think that opening up to mentor allows the latter to recognize and support the entrepreneur's needs. This suggests the following hypothesis:

H6: The mentee's high level of self-disclosure has positive impacts on the mentee's learning.

According to Dweck (1986), learning goal orientation is used in educational psychology to determine the nature of individual's cognitive and behaviour attitude. This is a relatively stable dispositional trait that individuals share in interpersonal relationships. On the one hand, individuals with a high learning goal orientation consider their intelligence as a malleable quality that can be developed by gaining knowledge and mastering difficult tasks (Button et al., 1996; Dweck, 1986). These individuals are driven by the need to broaden their skills and abilities, and to do so, they do not hesitate to take on difficult tasks or challenges. On the other hand, those with a low learning goal orientation perceive their intelligence as a constant or fixed entity, so they perceive their mistakes as a lack of 
competence and they avoid undertaking a job they think incapable of doing (Button et al., 1996; Dweck, 1986).

In a mentoring framework, Wanberg et al. (2003) argue that the level of learning goal orientation of the dyad members can affect the quality of the mentoring relationship in regards to learning. In accordance with this, authors note the positive relation between learning goal orientation, mentor's functions, and mentoring outcomes (Egan, 2005; Godshalk and Sosik, 2003; Kim, 2007). Their findings indicate that the role model (Egan, 2005), career-related and psychological functions are used more sufficiently when both participants have a high learning goal orientation (Godshalk and Sosik, 2003). These authors also demonstrate that in a high learning goal orientation, the mentee perceives positive professional outcomes from this relationship (job satisfaction, determination in goal achievement, climbing the corporate latter). In other words, the more the mentee seeks learning opportunities, the more the mentor deploys his functions, the more beneficial are the outcomes generated from this relationship. This suggests the following hypothesis:

H7: The mentee's learning goal orientation has positive impacts on the mentee's learning.

\subsection{The mentor's characteristics}

In an entrepreneur-mentoring context, the mentor's business experience can influence the quality of the mentoring relationship. For example, Barrett (2006) illustrates that mentees who were satisfied with the mentoring relationship are those who had a mentor with experience and who understood their issues, whereas those who were dissatisfied are those who had a mentor with a lack of business experience. Cull (2006) also suggests that 
experienced mentors, because of their professional background, can easily define the mentee's difficulties, give better advice for decision-making, and initiate more ideas and options when faced with entrepreneurial difficulties (Krueger, 1998). These considerations suggest the following hypothesis:

H8: The mentor's experience in an entrepreneurial career positively influences the mentee's learning.

Similarly, the results of Wikholm et al. (2005) reveal that more than 71 percent of the respondents agree that having a mentor in the same industry as them is optimal. Furthermore, other studies highlight the mentee's dissatisfaction regarding a mentor without experience in the same industry (Bisk, 2002). Thus, having an experienced mentor in the same field of work is perceived beneficial by the mentee for it improves his or her level of learning. However, entrepreneurs expect to share general business knowledge, but they do not sense the necessity for their mentor to have an in-depth expertise in the same field of activities other than their own (Bisk, 2002). Despite this, it is quite possible that having a mentor in the same industry as the mentee facilitates even more the learning. This suggests the following hypothesis:

H9: Mentor's experience in the same industry as the mentee has positive impacts on the mentee's learning.

\section{Methodology}

This study is based upon data collected from Réseau $M$, a business-mentoring network developed by the Fondation de l'entrepreneurship. It is a non-profit organization dedicated 
to the economic development and promotion of entrepreneurial culture in the province of Quebec. Réseau $M$ was created in 2000 and is offered to novice entrepreneurs. There are seventy mentoring cells throughout Quebec. The services are supported by a series of economic development organizations such as: local development centres (LDC's), Community Futures Development Corporations (CFDCs) and local chambers of commerce. Each cell has a coordinator that recruits and supervises the mentor's training, promotes mentoring among novice entrepreneurs, ensures pairing entrepreneurs and mentors on the basis of previously established objectives, guides and organizes the terms of the mentoring relationship. Each year, nearly 1,700 entrepreneurs benefit from this low cost mentoring service (a few hundred dollars per year) with their 1,200 certified mentors and volunteers available to support them.

\subsection{Sample and data collection}

The sampling was composed of all the novice entrepreneurs who had participated in the Fondation de l'entrepreneurship mentoring program. The respondents must have attended a total of at least three meetings or who were in the process of, and whose email address was valid at the time of the 2008 data survey. In total, 981 mentees were invited through email to take part in an online questionnaire. This allowed producing a pool of 360 respondents for a response rate of 36.9 percent. The missing data were excluded. The sample totals 314 mentees, which includes 162 men and 152 women. They were paired with 256 male mentors and 152 female mentors. Hence, the low number of female mentors in the mentoring program can be explained by the fact that 40 years ago there were fewer 
women entrepreneurs than today. The data sample indicates that mentees have a relatively high education rate because 40.4 percent of the respondents have a university undergraduate degree, 28 percent have a college degree, 16.9 percent have a high school education, and 14.6 percent have a second or third level university degree. The average age of the respondent's is 39.81 years (standard deviation of 8.97 and median of 38 years old). As for the professional profile, the majority of the mentee's (51.1\%) had no business experience at the time of the start-up, 63.4 percent had less than one year, 73.6 percent less than three years and 82.9 percent less than five years. Twenty-four percent of the mentees said having no experience in their field of business, 33.2 percent less than one year of experience, 46.2 percent less than three years, and 61.6 percent less than five years. Finally, it is noteworthy that the majority of the mentees (93.3\%) had an active business at the time of the pairing, whereas only 6.7 percent were at the start-up process. These businesses count an average of 4.48 employees. Also, 62.8 percent of them record an annual turnover of less than $\$ 100,000,88.9$ percent cumulate an annual turnover of less than $\$ 500,000$, and only 8.6 percent generate an annual turnover of more than one million dollars.

Regarding mentors, the data shows that the majority of the mentors (47.9\%) are, or have been, business entrepreneurs, and that many of them (34.3\%) fulfill, or have fulfilled, the role of manager for a private business, and a small percentage $(6.8 \%)$ represent those who work, or have worked, as public servant. As for the other mentors (10.9\%), either their field of work was not taken into consideration by the mentee at the time of the pairing, or they did not want to answer. It was also noted that the majority of the mentors $(57.4 \%)$ were retired at the time of the pairing, and that less than half $(40.8 \%)$ were still 
professionally active. Lastly, it was noted that the majority of the mentors $(79.6 \%)$ were not involved in the same industry as their mentee. This finding is not surprising, since to ensure a relationship based on mentoring and not on coaching, the Réseau $M$ focuses on dyads consisting of mentors and mentees from different fields of work. This explains why only $24.4 \%$ of the mentors have worked in the same industry as their mentee at the time of the pairing.

\subsection{Measures}

\subsubsection{Self-Disclosure}

The mentee's self-disclosure is measured using a scale developed by Miller's et al. (1983). The respondents were asked to select on a 7-point Likert Scale their level of agreement or disagreement, ranging from "1- I would never discuss this matter" to "7- I would discuss this matter openly", and to what extend mentees would open up to strangers of same gender regarding personal matters such as habits, manners, intimacy, fears, and others. The internal consistency coefficient (Cronbach's alpha) for this measure scores 0.899 , which is deemed acceptable (Tabachnick and Fidell, 2007).

\subsubsection{Learning goal orientation}

The measure used is the one developed by Button et al. (1996). It consists of eight items that measure the mentee's attitude towards learning opportunities such as: "It is important for me to have the opportunity to accomplish something challenging"; "When faced with a difficult situation I like trying different approaches to see which one will work", and so on. 
The respondents could also mark their answers using the 7-point Likert Scale ranging from: "1 - Strongly disagree" to "7 - Strongly agree". The internal consistency analysis indicated a Cronbach's alpha of 0.927 , which is acceptable.

\subsubsection{Mentor's professional career and industry background}

The mentor's professional career was coded using a binary variable, where $0=$ mentors who are (or who were) entrepreneurs, and $1=$ mentors who fulfill (or who have fulfilled) a different occupation. As for the mentor's industry background, it is also measured using a binary variable. The mentee was asked to indicate whether yes (1) or no (0) the mentor had worked in the same business sector as himself.

\subsubsection{Trust in mentor}

The mentor's trust (measure) was developed for this study and is based on the three components of trust proposed by Rempel and Holmes (1985). A 7-point Likert Scale ranging from "1 - Strongly disagree" to "7 - Strongly agree" was also used for the following items: 1- I can trust my mentor; 2- My mentor is trustworthy and I can rely on him or her; 3- My mentor is predictable. The Cronbach's alpha for this measure is 0.741 , which is deemed acceptable.

\subsubsection{Perceived similarity}

Perceived similarity is measured using four items. The three first items refer to the measures developed by Allen and Eby (2003), and the fourth one refers to the Ensher and 
Murphy (1997) measure. Here also the mentees expressed their level of agreement or disagreement using a Likert Scale ranging from "1 - Strongly disagree" to "7 - Strongly agree", regarding the following statements: 1- My mentor and I share the same values; 2My mentor and I share the same interests; 3- My mentor and I have similar personalities; 4- My mentor and I see things the same way. The Cronbach's alpha for this measure is 0.897 , therefore, acceptable.

\subsubsection{Mentor's functions}

The mentor's function was measured using an instrument developed by St-Jean (2011). It illustrates the level of mentoring received by the mentee. Regarding to career-related functions, the mentee was asked to express the level of support given by the mentor regarding his or her entrepreneur career. Sixteen items were retained to operationalize the career-related functions. As follows are some of the items used: "My mentor provides technical information;" "My mentor introduces me to his or her contacts;" "My mentor allows me to anticipate the consequences of my decisions," and so on. As for psychological functions, the mentee noted the level of psychological support given by the mentor. Fourteen items were used to measure this variable, such as: "My mentor reassures me;" "My mentor allows me to clearly visualize myself and my business," and so on. Lastly, for the role-model function the mentee had to indicate to what extend the mentor was a role model using four items such as: "My mentor shares with me his successes and failures," and so on. Regarding these functions, the mentee also rated his or her opinion using a 7point Likert Scale varying from "1 - Strongly disagree" to "7 - Strongly agree". Moreover, 
the coefficient (Cronbach's alpha) for career-related functions rates 0.942 , psychological functions 0.959 , and role model function 0.894 .

\subsubsection{Learning with mentor}

This measure is inspired by the one developed by Allen and Eby (2003); it consists of the following five items: 1- I learned a lot from my mentor; 2- My mentor gave me new perspectives regarding different things; 3- My mentor and I were "co-learners" in the mentoring relationship; 4- There was reciprocal learning that took place between my mentor and I; 5- My mentor shared a lot of information that helped me in my professional development. The respondents marked their answers on a 7-point Likert Scale ranging from "1- Strongly disagree" to "7- Strongly agree". For this measure, the Cronbach's alpha rates 0.91 .

\subsubsection{Control variables}

The controlled variables illustrate certain demographic characteristics such as the mentee's age, gender (mentee and mentor) and the mentee's level of education.

\subsection{Method used}

In order to verify our hypothesis, a hierarchical regression was done to measure the impact of certain factors on mentee's learning. Firstly, we started by including controlled variables in the first model, and for the second model we added self-disclosure and learning goal orientation. As for the third model, variables such as "mentor's gender", "mentor's career", 
and "mentor's industry background" were added. The fourth model contains other variables such as "trust in the mentor", "perceived similarity with the mentor". Lastly, the fifth model corresponds to the three major functions of the mentor, such as, career-related, psychological, and role model. We decided to include the mentor's functions last, since they are most likely to have a direct impact with the mentee's learning and to emphasize the other factors that may influence learning. Also, this way of analyzing is particularly interesting since it not only shows the respective contributions of each variable regarding the mentee's learning, but also allows a general examination of the proposed model as a conceptual framework based on the work of Wanberg et al. (2003).

\section{Results}

Table 1 illustrates the means, standard deviations and the correlation between independent variables and the mentee's learning. There are no irregularities between the variables. 
Table 1. Means, Standard Deviation and Correlation between Variables

\begin{tabular}{|c|c|c|c|c|c|c|c|c|c|c|c|c|c|c|c|}
\hline Variables & Mean & S.-D. & 1 & 2 & 3 & 4 & 5 & 6 & 7 & 8 & 9 & 10 & 11 & 12 & 13 \\
\hline 1-Learning & 5,09 & 1,43 & & & & & & & & & & & & & \\
\hline 2-Gender & 0,48 & 0,50 &, 02 & & & & & & & & & & & & \\
\hline 3-Âge & 39,81 & 8,97 &,$- 11^{*}$ &,- 01 & & & & & & & & & & & \\
\hline 4-Edu. & 2,53 & 0,94 &, 00 &, $12^{*}$ &, 08 & & & & & & & & & & \\
\hline 5-Self-dis. & 4,77 & 1,27 &, $16^{* *}$ &, 00 &,- 04 &,- 05 & & & & & & & & & \\
\hline 6-LGO & 6,24 & 0,88 &, 00 &, $12^{*}$ &,- 05 &,- 02 &, $13^{*}$ & & & & & & & & \\
\hline 7-M.sex & 1,19 & 0,39 &, 01 &, $33 * *$ &, 00 &,- 02 &, 00 &, 02 & & & & & & & \\
\hline 8-M.career & 0,48 & 0,50 &, 07 &,- 03 &,$- 16^{* *}$ &,- 11 &, 04 & ,02 &, 01 & & & & & & \\
\hline 9-M.Indus & 0,81 & 0,40 & ,03 &,- 04 &, 01 &,- 03 &, 02 & 00 &,- 06 &,- 01 & & & & & \\
\hline 10-Trust & 5,75 & 1,16 &, $64 * *$ &,- 07 &,$- 16^{* *}$ &,- 06 &, 04 &,- 02 &,- 03 &,- 04 &,- 07 & & & & \\
\hline 11-Simili. & 4,71 & 1,40 &, $69 * *$ &, 00 &,- 14 &,- 09 &, $15^{* *}$ &, 00 & ,09 & ,08 &,- 07 &, $64 * *$ & & & \\
\hline 13-Psy.F & 5,23 & 1,21 &, $76^{* *}$ &, 07 &,$- 14^{*}$ &,- 02 &, $15^{*}$ &, 00 &, 11 &, 05 &, 03 &, $62 * *$ &, $64 * *$ &, $88^{* *}$ & \\
\hline 14-Mod.F & 5,39 & 1,43 &, $67 * *$ & ,03 &,$- 13^{*}$ &,- 04 &, $12^{*}$ & ,03 & ,03 &, $18^{* *}$ &,- 01 &, $48 * *$ &, $58 * *$ &, $77 * *$ &, $75^{* *}$ \\
\hline
\end{tabular}




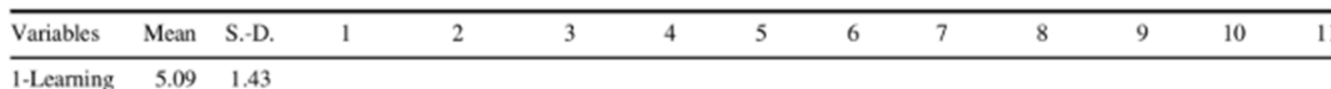

Table 2 illustrates that once all the variables are considered in the model, self-disclosure has no effect on the mentee's learning (standardized $\beta=0.068 ; p>0.05$ ). Consequently, H6 is rejected. Regarding the learning goal orientation, this variable shows no significant relation with the mentee's learning (standardized $\beta=0.002 ; p>0.05$ ). This brings $\mathrm{H} 7$ to be rejected. It is noteworthy that no significant relation exists between the mentor's professional career and the mentee's learning (standardized $\beta=0.036 ; p>0.05$ ). Also, the results show no significant relation between the mentor's industry background and the mentee's learning (standardized $\beta=0.015 ; p>0.05$ ). The addition of the mentor's professional career and industry background variables were not significant, therefore rejecting $\mathrm{H} 8$ and $\mathrm{H} 9$. Trust in the mentor does have a positive impact on the mentee's learning (standardized $\beta=0.205 ; p \leq 0.001$ ), just as perceived similarity (standardized $\beta=$ $0.0234 ; \leq 0.001$ ), leading to accept $\mathrm{H} 4$ and $\mathrm{H} 5$. The addition of these variables in model 4 explain the 56.5 percent variability of the mentee's learning, which means trust and perceived similarity increase the variance related to the mentee's learning by 51.6 percent $\left(\Delta \mathrm{R}^{2}\right)$. Finally, regarding the mentor's functions, it is noteworthy that the career-related functions (standardized $\beta=0.176 ; p \leq 0.05$ ) and psychological functions (standard $\beta=$ $0.237 ; \mathrm{p} \leq 0.01$ ) have positive impacts on the mentee's learning, but not the role model function, leading to accept $\mathrm{H} 1$ and $\mathrm{H} 2$ and reject $\mathrm{H} 3$. As shown in model 5, the coefficient of determination $R^{2}$ varies from 56.5 percent to 68.6 percent. This illustrates that the addition of the mentor's functions increases the variance related to the mentee's learning by 12.1 percent. 
Table 2. Hierarchical Regression Analysis of the Entrepreneur's Learning

\begin{tabular}{|c|c|c|c|c|c|}
\hline & $\begin{array}{c}\text { Model } 1 \\
\text { Std. } \beta\end{array}$ & $\begin{array}{c}\text { Model } 2 \\
\text { Std. } \beta\end{array}$ & $\begin{array}{c}\text { Model } 3 \\
\text { Std. } \beta\end{array}$ & $\begin{array}{c}\text { Model } 4 \\
\text { Std. } \beta\end{array}$ & $\begin{array}{c}\text { Model } 5 \\
\text { Std. } \beta\end{array}$ \\
\hline Mentee's gender & 0.027 & 0.029 & 0.017 & 0.063 & 0.021 \\
\hline Mentee's age & $-0.133^{*}$ & $-0.132 *$ & $-0.126^{*}$ & 0.005 & 0.019 \\
\hline Level of education & -0.010 & -0.007 & 0.000 & 0.070 & 0.034 \\
\hline Self-disclosure & & $0.175^{* *}$ & $0.174 * *$ & $0.093^{*}$ & 0.068 \\
\hline LGO & & -0.021 & -0.019 & 0.010 & 0.002 \\
\hline Mentor's gender & & & 0.036 & -0.008 & -0.025 \\
\hline Mentor's career & & & 0.038 & 0.078 & 0.036 \\
\hline Mentor's ind. backg. & & & -0.011 & 0.063 & 0.015 \\
\hline Trust & & & & $0.401 * * *$ & $0.205 * * *$ \\
\hline Perceived similarity & & & & $0.425 * * *$ & $0.234 * * *$ \\
\hline Career functions & & & & & $0.176^{*}$ \\
\hline Psych. functions & & & & & $0.237 * *$ \\
\hline Role-model function & & & & & 0.116 \\
\hline Sig. F Variation & 0.174 & 0.019 & 0.868 & 0.000 & 0.000 \\
\hline$R^{2}$ & 0.019 & 0.049 & 0.052 & 0.565 & 0.686 \\
\hline
\end{tabular}

\section{Discussion}

As expected, the results illustrate that trust is a key element in the mentee's learning. In other words, the more the entrepreneur trusts his or her mentor, the more he will learn from him or her. In the same vein, the more the mentee perceives similarity with his or her mentor in terms of values, interests, and personality, the more he or she will learn from the mentoring relationship. These results confirm the findings of Hale (2000), which show the positive impacts between the level of perceived similarity and the mentee's learning. Because the novice's level of learning is higher when he or she perceives similarity with his or her mentor, in terms of values, personality, and attitudes, one could assume that 
learning would be based on information from strong signal networks (Julien et al., 2004). This would allow the novice entrepreneur to have confidence in his decision-making.

Also, our findings illustrate the key roles career-related and psychological functions play in the mentee's learning. As for the career-related functions, we notice that the mentor's support regarding the mentee's professional development (sharing professional information, networking, and so on) allows the latter to heighten his level of learning. Our findings also confirm those observed in an organizational mentoring framework, where career-related functions are directly related to the protégé's learning (Lankau and Scandura, 2002; Wanberg et al., 2003). Therefore, this study provides additional information with regards to the specific career-related functions in the mentee's learning. Our results demonstrate that psychological functions also contribute to the mentee's learning. Psychological functions aim to support the mentee in his personal development and they can be observed, among others, by the consolidations of the mentee's sense of self-confidence, reassurance, and self-control in times of stress. Thus, the mentee's learning resulting from the psychological functions could be related to the development of general attitude and affective learning. Therefore, this confirms previous findings in organizational mentoring frameworks (Wanberg et al., 2003) regarding the mentor's functions in the development of the mentee's affective learning.

Furthermore, our findings show that the role-model function has no impact on the mentee's learning. However, the social learning theory posits that people learn from others they consider as role models (Bandura, 1999). Yet, this theory specifies that in order to learn one must observe and imitate their model's behaviour within similar conditions. In 
an organization framework, Lankau and Scandura (2002) show, for example, that a protégé who attends a meeting conducted by his or her mentor will observe and learn from the latter's behaviour and therefore, in turn, will conduct successful meetings. Thus, the role model function may have no impact on the mentee's learning because to learn from the mentor's experience and to develop future skill, the mentee must share similar life experiences. As such, it is therefore, possible that perceived similarity, a significant dimension needed to make the learning happening, could lessen the impact of role model function on learning. As we have seen, perceived similarity is strongly correlated with the role model function. Although not tested here, perceived similarity could act as a moderator, where high perceived similarity would improve the effect of role modelling on learning. Thus, the effect of role model function on learning would be less visible when perceived similarity is considered in the analysis, which is the case in the final model proposed.

Regarding the mentee's characteristics, the lack of correlation between the mentee's self-disclosure (such as thoughts, feelings, opinions) and learning leads us to believe that self-disclosure has no impact on his or her level of learning. However, it is noteworthy that for the purpose of this study, the scale used for measuring self-disclosure is general, it is not specific to mentors. Thus, the use of a more specific measure could have given different results. Furthermore, we cannot exclude the possibility that the mentee's lack of self-disclosure could cause the mentoring relationship to fail, thus bringing it to an end. Consequently, it seems reasonable to believe that we are in the presence of a mentoring relationship with a high level of self-disclosure, and without sufficient self-disclosure the 
mentoring relationship would not be possible. It is also likely that the mentee's selfdisclosure is apprehended through trust in the mentor, based on the fact that without sufficient self-disclosure on the part of the mentee, it is unlikely that the relationship would bring enough trust in the mentor. Since the trust measure is more specific to this context, it is possible that it may have lowered the empirical relationship between self-disclosure and the mentee's learning. This could explain why self-disclosure is significant for the first model and not for the complete model (model 5).

Regarding the learning goal orientation, the findings show that this variable has no impact on the mentee's learning. Thus, our findings varied from those observed in an organizational mentoring context (Godshalk and Sosik, 2003; Wanberg et al.., 2003). In regard to an entrepreneur-mentoring framework, the lack of significant correlation between the two variables may thus appear surprising. Yet, our study demonstrates that the participating mentees have a high level of learning goal orientation (mean of 6.24 on a 7point Likert scale). Moreover, the 0.88 standard deviation suggests that our observations fall closely to the mean; therefore, we have a homogeneous sampling. These statistics illustrate that many of the entrepreneurs used for this study have a high level of learning goal orientation, thereby lowering the variance shared with the mentee's learning. So, the low variance could explain the absence of correlation between the mentee's learning goal orientation and the mentee's learning.

Finally, regarding the mentor's characteristics, our findings do not allow us to believe if the mentee's learning would be better supported from a mentor with an entrepreneurial career versus one working for an organizational environment or public 
service. Yet, studies show that pairing a mentee with an experienced entrepreneur is beneficial for the mentee's learning (Barrett, 2006; Cull, 2006; Krueger, 1998). Our findings illustrate that the novice entrepreneur's learning is based on different criteria. However, it is noteworthy that the measure used for the mentee's learning is general and not specific to this study. It is possible to believe that for certain specific learning, pairing a mentee with an experienced mentor could make a difference, such as identifying business opportunities (Ozgen and Baron, 2007).

In the same vein, our results do not allow us to believe if pairing a mentee and mentor working in the same industry facilitates the mentee's learning. Researchers remain divided regarding this fact. Some think it is necessary (Simard and Fortin, 2008; Wikholm et al.., 2005), while others share different opinions (Bisk, 2002; Nandram, 2003). In the end, the non-significant correlation between the mentor's industry background and mentee's learning leads us to believe that entrepreneurs participating in the mentoring relationship seek more than acquiring individual expertise related to their field of work.

Other limits can be underscored for this study. Given the mentor's supportive role regarding the mentee's learning, it would have been interesting to have their perception regarding their actual role in the mentoring relationship. The transversal nature of this research also leads us to recommend a longitudinal study since the benefits regarding learning often develop with time. In some cases, learning can be immediate, for example, when the mentor shares contacts in order to support the mentee's project. Other learnings may take longer or even develop in interaction with other factors, for example, when the mentee learns to use his or her leadership amongst employees. These learnings are not only 
time consuming, but also involve situations where the mentee can put his or her leadership into practice, on the one hand, and where the mentee can seek advice from his or her mentor, on the other hand.

\section{Conclusion}

Finally, this study has allowed identifying several interesting results. Firstly, the benefits that mutual trust and perceived similarity have on the mentee's learning emphasize the universality of certain concepts regarding the mentoring relationship. The importance of trust and perceived similarity indicates that interpersonal comfort is beneficial for the mentee's learning. Second, the study has illustrated the important role that career-related and psychological functions play in the mentee's learning. These usually occurs through concrete actions taken by the mentor, such as sharing professional information, suggesting business contacts, supporting and reassuring the mentee. Therefore, mentors should be given a formal guidebook emphasizing these factors, as well as training before the first pairing. Continuous training could also be a relevant way to remind this to the mentors and make them remain effective. Third, because the mentor's experience do not influence mentee's learning, it appears that the pairing mechanism would not need to take this in consideration. Instead, the most effective way to do the pairing could be to let the mentee choose his/her mentor. Indeed, as perceived similarity and trust are the most important aspects to support entrepreneurial learning, a freely made pairing would let mentees find by themselves the best fit within the available mentors. Finally, this study has allowed a better understanding of the benefits of mentoring, and more specifically, regarding the 
beneficial impacts it has on the novice entrepreneurs' learning. However, this contribution

follows in the footsteps of previous studies and opens the path to future questions, which

hopefully, will be resolved in the future.

\section{References}

Allen, T. D., Eby, L. T. (2003). Relationship effectiveness for mentors: Factors associated with learning and quality. Journal of Management, 29(4), 469.

Allen, T. D., Eby, L. T. (2004). Factors related to mentor reports of mentoring functions provided: Gender and relational characteristics. Sex Roles, 50(1), 129-39.

Alred, G., Garvey, B. (2000). Learning to produce knowledge-the contribution of mentoring. Mentoring and tutoring, 8(3), 261-72.

Bandura, A. (1999). Social cognitive theory: An agentic perspective. Asian Journal of Social Psychology, 2(1), 21-41.

Barczyk, C, Buckenmeyer, J., Feldman, L., and Hixon, E. (2011). Assessment of a university-based distance education mentoring program from a quality management perspective. Mentoring \& Tutoring: Partnership in Learning, 19(1), $5-24$.

Barnir, A. (2014). Gender differentials in antecedents of habitual entrepreneurship: Impetus factors and human capital. Journal of Developmental Entrepreneurship, $19(01), 1450001$.

Barrett, R. (2006). Small business learning through mentoring: Evaluating a project. Education \& Training, 48(8/9), 614.

Bisk, L. (2002). Formal entrepreneurial mentoring: The efficacy of third party managed programs. Career Development International, 7(5), 262-270.

Blickle, G., Schneider, P. B., Perrewé, P. L., Blass, F. R., and Ferris, G. R. (2008). The roles of self-disclosure, modesty, and self-monitoring in the mentoring relationship. Career Development International, 13(3), 224.

Bouquillon, E. A., Sosik, J. J., and Lee, D. (2005). 'It's only a phase': Examining trust, identification and mentoring functions received across the mentoring phases. Mentoring \& Tutoring: Partnership in Learning, 13(2), 239-258.

Boyd, D. P., and Gumpert, D. E. (1983). Coping with entrepreneurial stress. Harvard Business Review, 61(2), 44-64.

Burke, R. J., McKeen, C. A., and McKenna, C. (1994). Benefits of mentoring in organizations: The mentor's perspective. Journal of Managerial Psychology, 9(3), 23-32.

Button, S., Mathieu, J., and Zajac, D. (1996). Goal orientation in organizational research: A conceptual and empirical foundation. Organizational Behavior and Human Decision Processes, 67, 26-48.

Byrne, D. E. (1971). The attraction paradigm: Academic Press.

Chrisman, J. J., and McMullan, W. (2004). Outsider assistance as a knowledge resource for new venture survival. Journal of Small Business Management, 42(3), 229-244. 
Chun, J., Litzky, B., Sosik, J., Bechtold, D., and Godshalk, V. (2010). Emotional intelligence and trust in formal mentoring programs. Group \& Organization Management, 35(4), 421.

Clutterbuck, D. (1999). Mentoring in business: Executives and directors. Mentoring \& Tutoring: Partnership in Learning, 6(3), 76-84. doi: 10.1080/0968465990060306

Cope, J. (2005). Toward a dynamic learning perspective of entrepreneurship. Entrepreneurship theory and practice, 29(4), 373-397.

Cope, J., and Watts, G. (2000). Learning by doing - an exploration of experience, critical incidents and reflection in entrepreneurial learning. International Journal of Entrepreneurial Behaviour \& Research, 6(3), 104.

Cozby, P. (1973). Self-disclosure: A literature review. Psychological Bulletin, 79(2), 7391.

Cuerrier, C. (2004). Le mentorat et le développement professionnel. Incontournable: l'art de vivre en entreprise, 5.

Cull, J. (2006). Mentoring young entrepreneurs: What leads to success? International Journal of Evidence Based Coaching and Mentoring, 4(2), 8-18.

Deakins, D., Graham, L., Sullivan, R., and Whittam, G. (1998). New venture support: An analysis of mentoring support for new and early stage entrepreneurs. Journal of Small Business and Enterprise Development, 5(2), 151-161.

Dweck, C. S. (1986). Motivational processes affecting learning. American psychologist, 41(10), 1040.

Eby, L., Butts, M., Lockwood, A., and Simon, S. (2004). Protégés negative mentoring experiences: Construct development and nomological validation. Personnel Psychology, 57(2), 411-447.

Eby, L., McManus, S., Simon, S., and Russell, J. (2000). The protégé's perspective regarding negative mentoring experiences: The development of a taxonomy. Journal of Vocational Behavior, 57(1), 1-21.

Eby, L. T., and Allen, T. D. (2002). Further investigation of protégés' negative mentoring experiences patterns and outcomes. Group \& Organization Management, 27(4), 456-479.

Egan, T. M. (2005). The impact of learning goal orientation similarity on formal mentoring relationship outcomes. Advances in Developing Human Resources, 7(4), 489.

Ensher, E., Grant Vallone, E., and Marelich, W. (2002). Effects of perceived attitudinal and demographic similarity on protégés' support and satisfaction gained from their mentoring relationships. Journal of Applied Social Psychology, 32(7), 1407-1430.

Ensher, E., and Murphy, S. (1997). Effect of race, gender, perceived similarity, and contact on mentor relationships. Journal of Vocational Behavior, 50(3), 460-481.

Fleig-Palmer, M. M., and Schoorman, F. D. (2011). Trust as a moderator of the relationship between mentoring and knowledge transfer. Journal of Leadership \& Organizational Studies, 18(3), 334-343. doi: 10.1177/1548051811408615

Gartner, W. B., Starr, J. A., and Bhat, S. (1999). Predicting new venture survival: An analysis of "anatomy of a start-up." cases from inc. Magazine. Journal of Business Venturing, 14(2), 215-232. 
Gibb, A. (1997). Small firms' training and competitiveness. Building upon the small business as a learning organisation. International Small Business Journal, 15(3), 13.

Godshalk, V., and Sosik, J. (2003). Aiming for career success: The role of learning goal orientation in mentoring relationships. Journal of Vocational Behavior, 63(3), 417437.

Gravells, J. (2006). Mentoring start-up entrepreneurs in the east midlands - troubleshooters and trusted friends. the international journal of mentoring and coaching, 4(2).

Hale, R. (2000). To match or mis-match? The dynamics of mentoring as a route to personal and organisational learning. Career Development International, 5(4/5), 223-234.

Hansford, B., Tennent, L., and Ehrich, L. C. (2002). Business mentoring: Help or hindrance? Mentoring and tutoring, 10(2), 101-115.

Julien, P.-A., Andriambeloson, E., and Ramangalahy, C. (2004). Networks, weak signals and technological innovations among smes in the land-based transportation equipment sector. Entrepreneurship \& Regional Development, 16(4), 251-269.

Kim, S. (2007). Learning goal orientation, formal mentoring, and leadership competence in hrd. Journal of European Industrial Training, 31(3), 181.

Kram, K. (1985). Mentoring at work: Developmental relationships in organizational life: Scott, Foresman Glenview, IL.

Kram, K. E. (1983). Phases of the mentor relationship. Academy of Management Journal, 26(4), 608-625.

Krueger, C. W. (1998). Mentoring the entrepreneur. Nursing Administration Quarterly, 22(2), 1.

Lankau, M., and Scandura, T. (2002). An investigation of personal learning in mentoring relationships: Content, antecedents, and consequences. Academy of Management Journal, 45(4), 779-790.

Leitch, C., Hill, F., and Henry, C. (2004). The effectiveness of training for new business creation: A longitudinal study. International Small Business Journal, 22(3), 249271.

Levin, D. Z., and Cross, R. (2004). The strength of weak ties you can trust: The mediating role of trust in effective knowledge transfer. Management science, 50(11), 14771490.

Lunt, N., Benett, Y., McKenzie, P., and Powell, L. (1992). Understanding mentoring. The Vocational Aspect of Education, 44(1), 135-141.

MacPherson, M. (2009). Entrepreneurial learning: Secret ingredients for business success. Training and Development.

Miettinen, A. (2003). Mentoring for entrepreneurs as an educational intervention. Paper presented at the Proceedings of IntEnt2003, Internationalizing Entrepreneurship Education and Training 13th annual Conference, 7-10 September 2003, France.

Miller, L. C., Berg, J. H., and Archer, R. L. (1983). Openers: Individuals who elicit intimate self-disclosure. Journal of personality and social psychology, 44(6), 1234.

Moreland, N., and Clark, M. (1992). Training and development for small business managers. Part one: A prologue - who are the small business managers? The 
Vocational Aspect of Education, 44(2), 211-232. doi: 10.1080/10408347308003931

Nandram, S. S. (2003). Entrepreneurs' need for mentoring and their individual differences.

Noe, R. A. (1988). An investigation of the determinants of successful assigned. Personnel Psychology, 41(3), 457.

Ozgen, E., and Baron, R. A. (2007). Social sources of information in opportunity recognition: Effects of mentors, industry networks, and professional forums. Journal of Business Venturing, 22(2), 174-192.

Politis, D. (2005). The process of entrepreneurial learning: A conceptual framework. Entrepreneurship theory and practice, 29(4), 399-424.

Rae, D., and Carswell, M. (2000). Using a life-story approach in researching entrepreneurial learning: The development of a conceptual model and its implications in the design of learning experiences. Education + Training, 42(4/5), 220-228.

Ragins, B. R. (1997). Diversified mentoring relationships in organizations: A power perspective. Academy of Management. The Academy of Management Review, $22(2), 482$.

Rempel, J. K., Holmes, J. G., and Zanna, M. P. (1985). Trust in close relationships. Journal of personality and social psychology, 49(1), 95.

Scandura, T. A. (1992). Mentorship and career mobility: An empirical investigation. Journal of Organizational Behavior, 13(2), 169.

Simard, P., and Fortin, J. (2008). Mentorat des entrepreneurs. Gestion, 33(1), 10-17.

St-Jean, E. (2009). Retombées et facteurs de succès d'une relation de mentorat d'entrepreneur novice selon la perspective du mentoré. Université Laval, Laval, Québec, Canada.

St-Jean, E. (2011). Mentor funtions for novice entrepreneurs. Academy of Entrepreneurship Journal, 17(1).

St-Jean, E., \& Audet, J. (2012). The role of mentoring in the learning development of the novice entrepreneur. International Entrepreneurship and Management Journal, 8(1), 119-140. doi: 10.1007/s11365-009-0130-7

Sullivan, R. (2000). Entrepreneurial learning and mentoring. International Journal of Entrepreneurial Behaviour \& Research, 6(3), 160-175.

Tabachnick, B. G., and Fidell, L. S. (2007). Using multivariate statistics: Pearson education inc. Boston, $M A$.

Tedder, M., and Lawy, R. (2009). The pursuit of 'excellence': Mentoring in further education initial teacher training in england. Journal of vocational education and training, 61(4), 413-429.

Turban, D., Dougherty, T., and Lee, F. (2002). Gender, race, and perceived similarity effects in developmental relationships: The moderating role of relationship duration. Journal of Vocational Behavior, 61(2), 240-262.

Valéau, P. (2006). «l'accompagnement des entrepreneurs durant les périodes de doute». Revue de l'Entrepreneuriat, 5(1), 31-57. 
Van Gelder, J., De Vries, R., Frese, M., and Goutbeek, J. (2007). Differences in psychological strategies of failed and operational business owners in the fiji islands*. Journal of Small Business Management, 45(3), 388-400.

Wanberg, C., Kammeyer-Mueller, J., and Marchese, M. (2006). Mentor and protégé predictors and outcomes of mentoring in a formal mentoring program. Journal of Vocational Behavior, 69(3), 410-423.

Wanberg, C., Welsh, E., and Hezlett, S. (2003). Mentoring research: A review and dynamic process model. Research in personnel and human resources management, 22, 39124.

Wanberg, C., Welsh, E., and Kammeyer-Mueller, J. (2007). Protégé and mentor selfdisclosure: Levels and outcomes within formal mentoring dyads in a corporate context. Journal of Vocational Behavior, 70(2), 398-412.

Waters, L., McCabe, M., Kiellerup, D., and Kiellerup, S. (2002). The role of formal mentoring on business success and self-esteem in participants of a new business start-up program. Journal of Business and Psychology, 17(1), 107-121.

Wikholm, J., Henningson, T., and Hultman, C. (2005). Demand of mentoring among new starters. Paper presented at the ICSB 50th World conference, international Council for Small Business, Washington, DC. 